J. Perinat. Med. 16 (1988) 53

\section{Effect of blood and meconium on the determination of phospholipids in amniotic fluid using high pressure liquid chromatography}

\author{
Thomas Heinze, Geno Kynast, Joachim Wolfram Dudenhausen, and Erich Saling \\ Institute of Perinatal Medicine, The Free University of Berlin and Department of \\ Obstetrics, Women's Hospital Berlin-Neukölln, Berlin, West Germany
}

\section{Introduction}

The determination of phospholipids in amniotic fluid is widely accepted for the assessment of fetal lung maturity. Most important determinations include the L/S ratio [7], the quantitative determination of lecithin (phosphatidylcholine PC) by thin layer chromatography [13] and by enzymatic determination $[5,12]$. Other phospholipids have also been detected by two-dimensional thin layer chromatography and the presence and relative concentration of phosphatidylglycerol (PG) and phosphatidylinositol (PI) have been reported to be indicators of fetal lung maturity $[3,9]$.

Clinically used methods which measure only lecithin or the $\mathrm{L} / \mathrm{S}$ ratio as well as unspecific tests such as the shake test [4] or the determination of the optical density at $650 \mathrm{~nm}$ [14] are not reliable in cases of contamination of the amniotic fluid by blood and meconium $[2,5,10,11]$. In these cases efforts were made to analyze phosphatidylglycerol (PG) by two-dimensional thin layer chromatography $[15,16]$. The results suggest that slightly stained meconium contamination does not hinder the detection of PG [16] and that the PG determination is independent of contamination with blood [15].

This study was designed to evaluate the effect of varying degrees of contamination by blood and meconium on the concentration of phospholipids in amniotic fluid. Phospholipids were analyzed by a new method using high pressure liquid chromatography (HPLC). The method is based on the procedure of BRIAND et al. [1]. We extended the method for the quantitative determination of several phospholipids. The new method allows the

\section{Curriculum vitae}

Thomas Heinze was born 1950 in Jena; he studied chemistry in Saarbrücken and Berlin, received diploma in 1974, graduated in biochemistry (Dr. rer. nat.) from the Technical University of Berlin in 1978. Later he studied medicine at the Free University of Berlin. Since 1979 he has worked as a biochemist in the Institute of Perinatal Medicine. Since 1984 he has been a physician at the department of obstetrics at the Women's Hospital in Berlin-Neukölln.

analysis not only of phosphatidylcholine (PC) and sphingomyelin (SP), but also of the minor phospholipids phosphatidylglycerol (PG), phosphatidylinositol (PI) and phosphatidylethanolamine $(\mathrm{PE})$ - in a single run.

\section{Material and methods}

\subsection{Material}

Uncontaminated amniotic fluid samples were obtained from patients at term by amniocentesis. Maternal blood was obtained by venipuncture, and meconium was obtained from term newborns. Amniotic fluid samples were centrifuged for 10 minutes at $700 \mathrm{~g}$ and the supernatants of the samples were decanted and pooled to provide sufficient volume. The pool was divided into several 
aliquots of $2.0 \mathrm{ml}$. Rising amounts of meconium were added to the aliquots. The specimens were vigorously shaken for 10 minutes to produce homogen meconium stained amniotic fluid samples with different levels of contamination. The maximum concentration was $5 \mathrm{mg}$ meconium $/ \mathrm{ml}$ amniotic fluid.

As regards blood contamination, increasing amounts of freshly taken blood were added to aliquots of $2.0 \mathrm{ml}$. The samples were shaken well to ensure homogen contamination. A maximum of $10 \mathrm{vol} \%$ blood contamination was used.

\subsection{Reagents}

The following phospholipids were obtained from Sigma (Munich, FRG): phosphatidylglycerol (PG) (ammonium salt, egg yolk), phosphatidylinositol (PI) (ammonium salt, soybean), phosphatidylethanolamine (PE) (lecitin Type III, egg yolk), phosphatidylcholine (PC) (lecithin Type III E, egg yolk), sphingomyelin (SP) (bovine brain) and lysolecithin (LL) (Type I, soybean). Acetonitrile (HPLC grade) was purchased from Baker, Deventer, Holland, and chloroform, acetone and methanol (p. a. grade) from Merck, Darmstadt, FRG. Further aqua tridest was used.

\subsection{Extraction}

The extraction of the phospholipids with chloroform-methanol $(2: 1, \mathrm{v} / \mathrm{v})$ was followed by the cold acetone precipitation according to GLUCK [8]. $40 \mu \mathrm{g}$ lysolecithin (LL) were added as internal standard to $2.0 \mathrm{ml}$ of amniotic fluid. Afterwards $4.0 \mathrm{ml}$ chloroform and $2.0 \mathrm{ml}$ methanol were pipetted to the sample. Then the tube was agitated vigorously for 2 minutes and deposited into an ice bath. After separation of phases, which can be accelerated by centrifugation at $800 \mathrm{~g}$, the bottom chloroform layer was transferred by a $5 \mathrm{ml}$ syringe to another centrifuge tube. Then the sample was dried by nitrogen and the extract was washed several times with $100 \mu \mathrm{l}$ chloroform-methanol $(2: 1, \mathrm{v} / \mathrm{v})$ to achieve complete dryness.

Acetone precipitation: $100 \mu \mathrm{l}$ of cold anhydrous acetone were added to the tube of dried extract, which had been placed in an ice bath for 5 minutes. Then the tube was shaken slightly until a white precipitate was formed. Now $0.75 \mathrm{ml}$ of cold, anhydrous acetone were added and the sample was put into an ice bath for 20 minutes.
Afterwards the tube was inverted and any residual acetone was dried under a stream of nitrogen. The precipitate was dissolved in $100 \mu \mathrm{l}$ chloroformmethanol $(2: 1, \mathrm{v} / \mathrm{v})$ and $20 \mu \mathrm{l}$ were injected into the HPLC injection plot.

\subsection{Chromatographic analysis}

The HPLC separations were carried out on HPLC equipment from Knauer, Berlin, FRG, consisting of the HPLC pumps, an HPLC programmer, an HPLC oven, and a variable wave-length detector. Quantitation was carried out by integration of the peak areas on a software integrator. The chromatographic separation was achieved on a $25 \mathrm{~cm}$ $\times 0.46 \mathrm{~cm}$ column packed with Lichrosorb DIOL $5 \mu$ from Merck, Darmstadt, FRG and on a $6 \mathrm{~cm}$

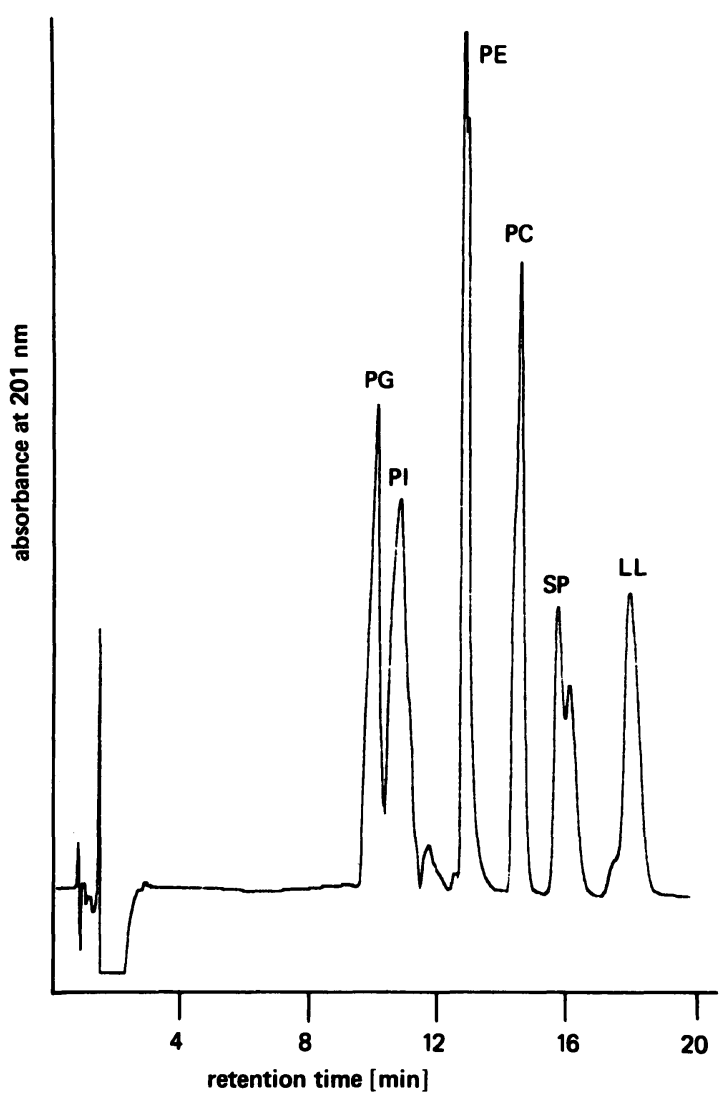

Figure 1. HPLC analysis of a standard solution containing 6 phospholipids. The amount injected was $2 \mu \mathrm{g}$ of each phospholipid. PG $=$ phosphatidylglycerol, PI $=$ phosphatidylinositol, $\mathrm{PE}=$ phosphatidylethanolamine, $\mathrm{PC}=$ phosphatidylcholine (lecithin), $\mathrm{SP}=$ sphingomyelin, $\mathrm{LL}=$ lysolecithin (internal standard). 
$\times 0.46 \mathrm{~cm}$ guard column packed with silica SI $605 \mu$ from Merck, Darmstadt, FRG. The oven temperature was $55^{\circ} \mathrm{C}$ and the detection wave length was $201 \mathrm{~nm}$. The chromatographic mobile phase was composed of solvent A: acetonitrile and solvent $B$ : acetonitrile/water $(4: 1, v / v)$. The following solvent gradient was used: start with $\mathrm{A}=88 \%, \mathrm{~B}=12 \%$, from 5 minutes until 8 minutes linear rise up to $B=23 \%$, from 8 to 12 minutes linear rise up to $\mathrm{B}=70 \%$ and after 13 minutes up to $B=75 \%$, from then on constantly until 18 minutes, between 18 and 19 minutes a linear drop to $B=12 \%$. The flow rate was constant at $2.5 \mathrm{ml} / \mathrm{min}$. Because the water gradient produces a rising baseline fluctuation, all chromatograms have to be baseline corrected.

The calibration curve was produced using a solution containing $2 \mu \mathrm{g}$ of each phospholipid (figure 1). The phospholipids PE, PC, SP and LL were baseline separated. To separate the PG and PI peaks a perpendicular division was necessary. For quantitative determination of the phospholipids we used an internal standard method with lysolecithin (LL) as internal standard. LL can be recommended as internal standard because of its retention time and its absence in amniotic fluid samples taken for the determination of fetal lung maturity. We found detectable amounts of LL only in samples of very mature amniotic fluid.

\section{Results and discussion}

Figure 2 shows two representative HPLC chromatograms of amniotic fluid samples, A uncontaminated and B contaminated with blood. The nearly complete separation of the phospholipids is demonstrated in figure $2 \mathrm{~A}$. Even at the highest contamination of amniotic fluid with $10 \mathrm{vol} \%$ blood (figure 2B) a sufficient separation of
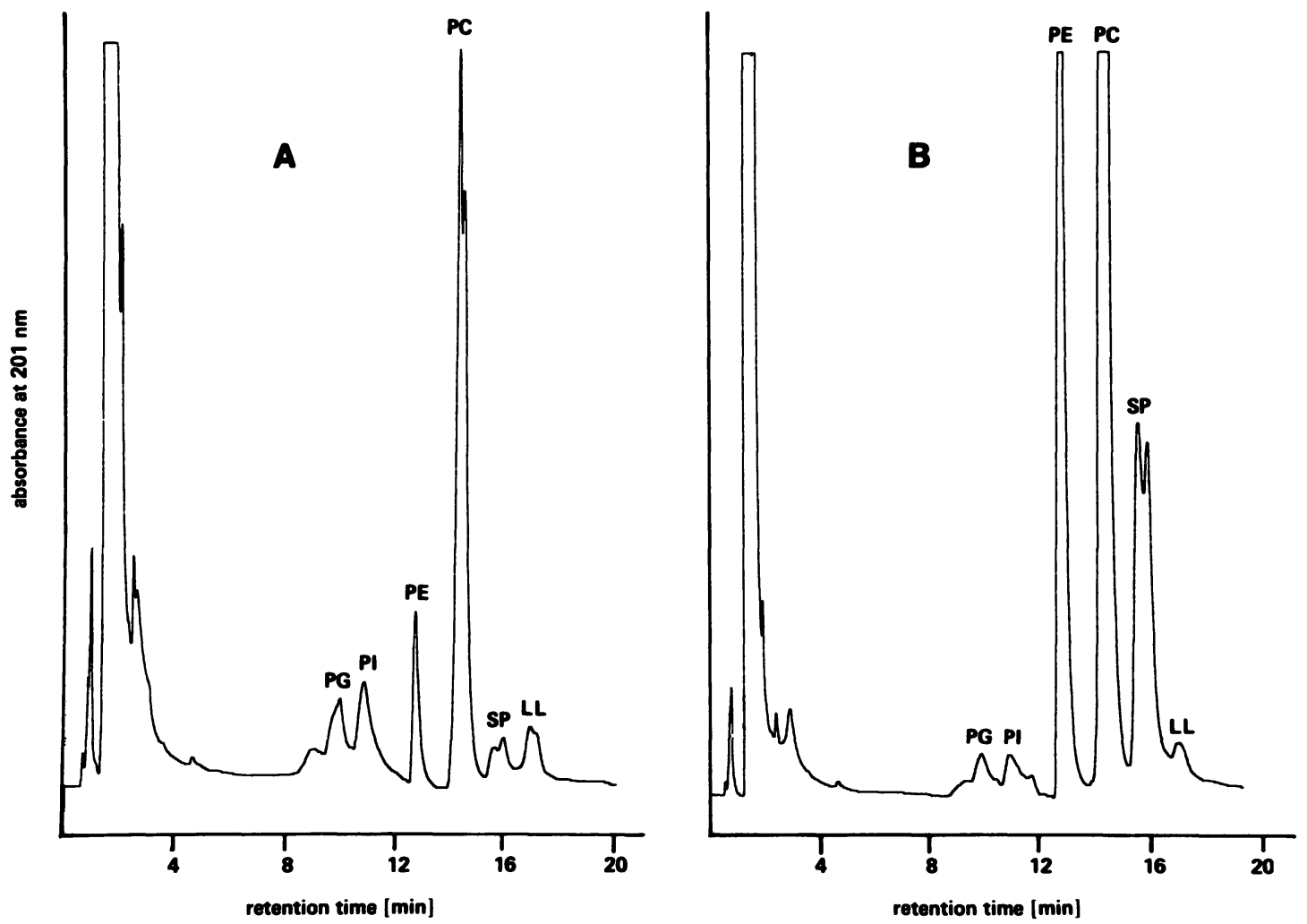

Figure 2. Phospholipids in amniotic fluid samples as determined by HPLC; (A) - uncontaminated, (B) - with 10 volume \% blood added. Peaks see figure 1. 


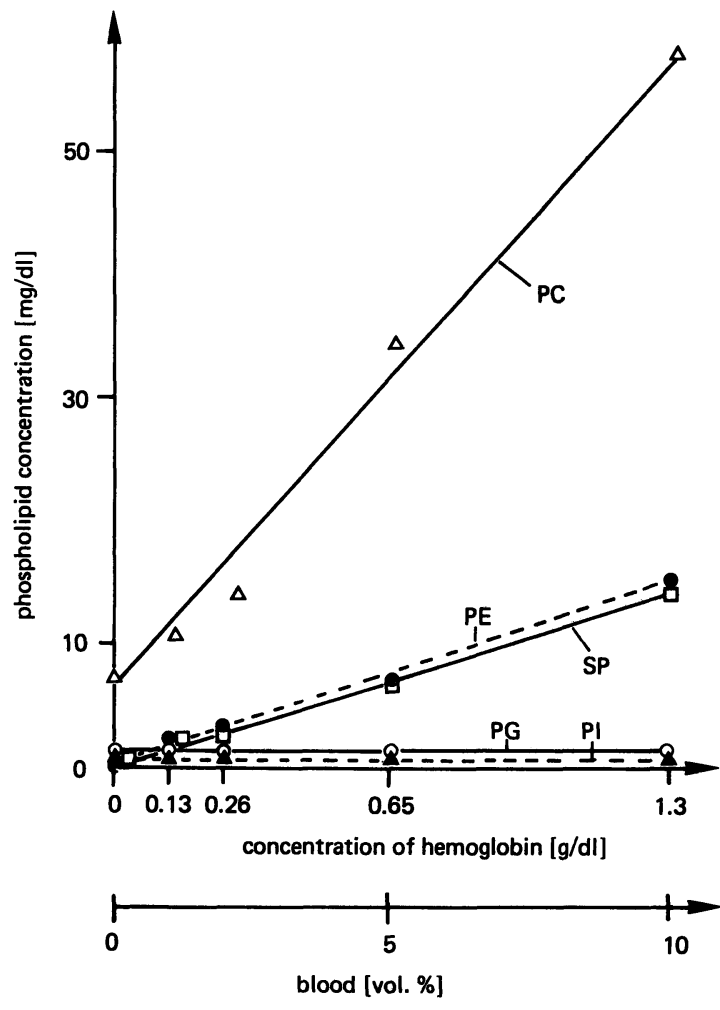

Figure 3. Phospholipids in amniotic fluid samples as determined by HPLC; influence of rising amounts of blood on the concentrations of PC $(\triangle), \operatorname{PE}(\bullet), \operatorname{SP}(\square)$, PG $(O)$ and PI $(\Delta)$. Blood contains $13 \mathrm{~g}$ hemoglobin/dl. Abbreviations see figure 1.

sphingomyelin and the internal standard is achieved. The strong rise of $\mathrm{PE}, \mathrm{PC}$ and $\mathrm{SP}$ in case of high blood contamination is obvious. Figure 3 shows the quantitative dependency of the phospholipid concentrations from rising blood contamination. The range goes up to $10 \mathrm{vol} \%$ blood. The solution containing $1.3 \mathrm{~g}$ hemoglobin/dl amniotic fluid is of distinct red color. In clinical routine such samples can mostly be avoided by cautious performance of amniocentesis. But even the slightest contamination of $1 \mathrm{vol} \%$ blood produces a clearly visible coloration of the amniotic fluid. The concentrations of PG and PI do not change when blood is added, even in highly contaminated samples. In the cases of PE and SP contamination may cause a rise up to ten fold. The PC concentration rises steeply up to a very high value of $60 \mathrm{mg} / \mathrm{dl}$.
To determine phospholipid concentrations in blood $2.0 \mathrm{ml}$ of freshly taken blood were extracted with chloroform-methanol according to chapter 2.3 without adding internal standard and the phospholipids were analyzed by HPLC. Figure 4 demonstrates the fact that blood contains only the phospholipids PE, PC and SP in detectable amounts, no PG and PI were to be found. This explains the strong increase of the concentrations of PE, PC and SP and the constant values of PG and PI in the case of blood contamination.

Figure 5 documents the influence of increasing meconium concentrations on the phospholipids in amniotic fluid. The colors of the meconium stained solutions varied from slightly green to dark green in case of $5 \mathrm{mg}$ meconium $/ \mathrm{ml}$ amniotic

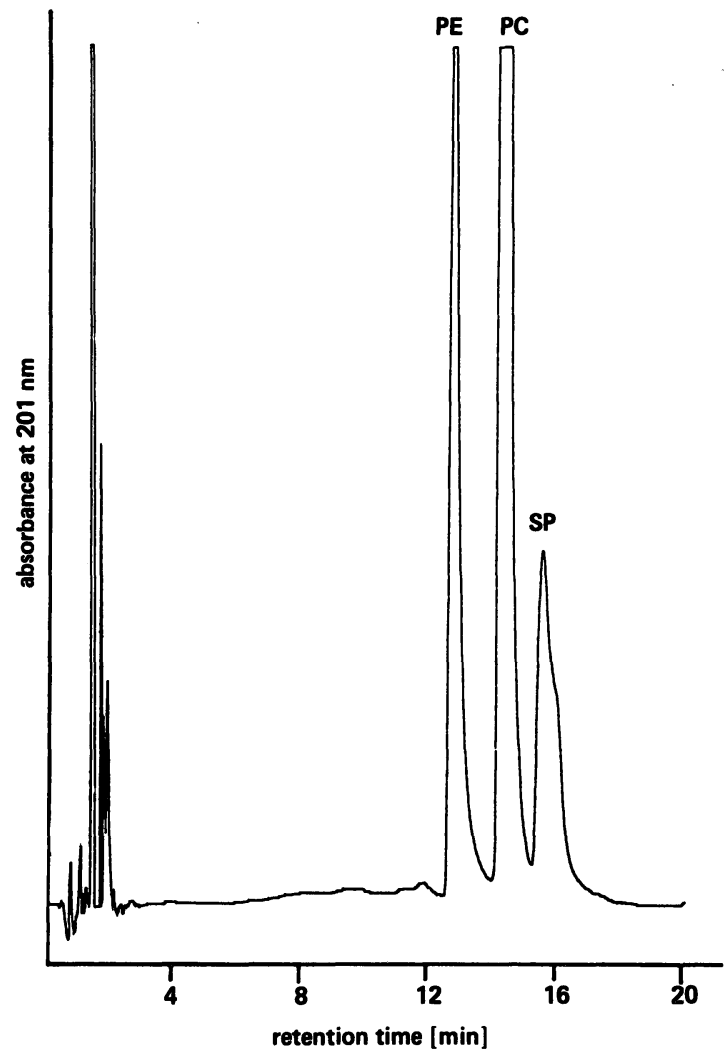

Figure 4. Phospholipids in a blood sample as determined by HPLC; extraction of $2.0 \mathrm{ml}$ blood with chloroformmethanol $(2: 1, \mathrm{v} / \mathrm{v})$ according to chapter 2.3 and dilution $1: 100$ with chloroform-methanol $(2: 1, \mathrm{v} / \mathrm{v})$. Peaks see figure 1 . 


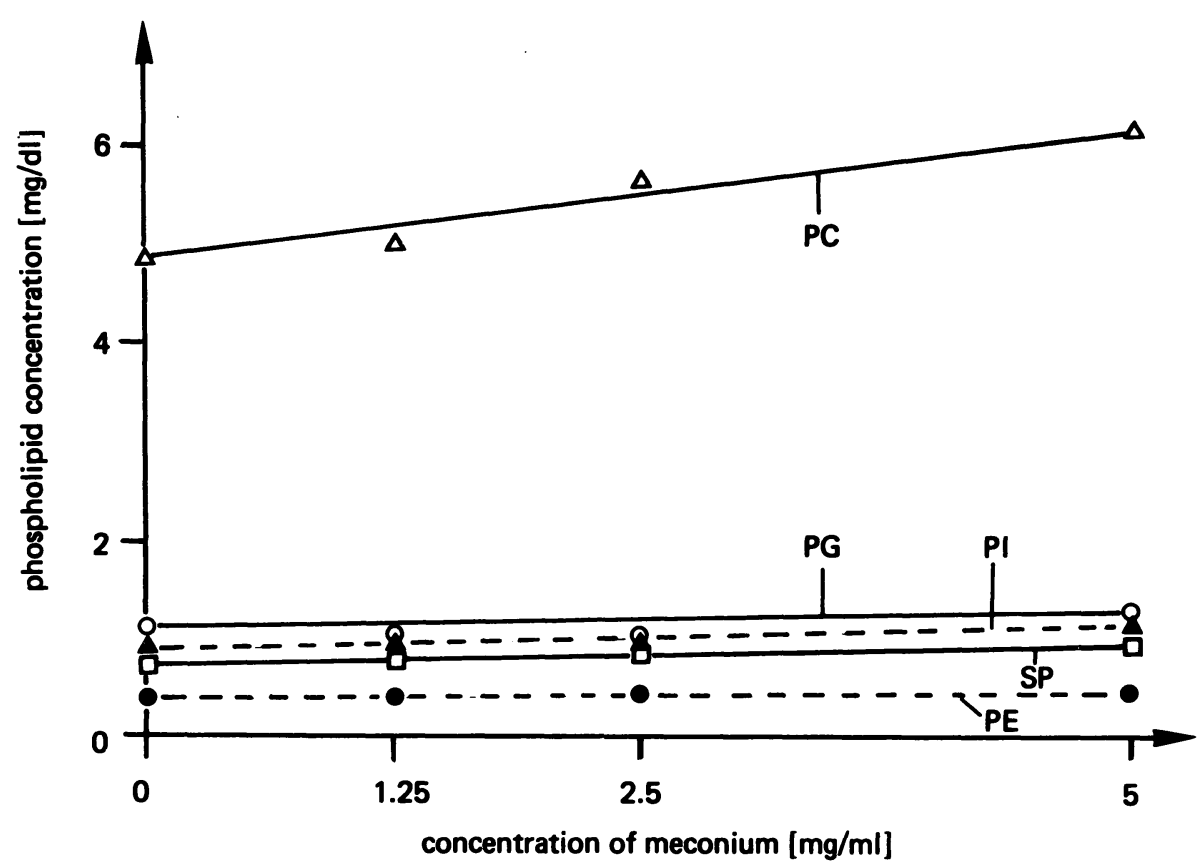

Figure 5. Phospholipids in amniotic fluid samples as determined by HPLC; influence of rising amounts of meconium on the concentrations of the phospholipids PE (O), SP ( $\square$ ), PI ( $\Delta$ ), PG (O) and PC ( $\triangle$ ). Abbreviations see figure 1 .

fluid. According to GARTZKe et al. [6] the maximum content of meconium in amniotic fluid will not exceed $6 \mathrm{mg} / \mathrm{ml}$. That is comparable to the highest meconium staining of $5 \mathrm{mg} / \mathrm{ml}$ amniotic fluid which we used. The concentrations of PG, $P I$ and PE do not change when meconium is added. Only in the case of PC and SP slight increases of about $20 \%$ resp. $10 \%$ at higher staining concentrations will occur. Figure 6 demonstrates the fact that meconium contains only PC and SP in detectable amounts, no PG, PI and PE were to be found.

When considering the estimation of fetal lung maturity, our results prove that there is no change of the concentrations of PG, PI and PE by meconium. Determination methods of fetal lung maturity, which are based on the analysis of PG are therefore reliable, even when the amniotic fluid is stained by meconium. This correlates well with JAMBAO et al. [16], who used the two-dimensional thin layer chromatography method and found that slightly stained meconium contamination does not hinder the determination of PG. The application of PC or SP for the assessment of fetal lung maturity is limited to slightly meconium stained samples. In cases of higher meconium contaminations, up to $20 \%$ higher PC values are determined.

If amniotic fluid is contaminated by blood the estimation of fetal lung maturity is more difficult. Only those methods are reliable, which are based on the determination of PG or PI. These findings correlate well with the results of STRASSNER et al. [15], who showed that PG analyzed by twodimensional thin layer chromatography is not influenced by blood contamination.

Other phospholipids like PE, PC and SP are not reliable as indicators of fetal lung maturity in cases of contamination due to blood. Even $1 \mathrm{vol} \%$ of blood causes a minimum of $50 \%$ increase of the different phospholipid concentrations.

In conclusion, our results show that only PG and PI values are independent of contamination with meconium or blood. PE is not influenced by meconium staining, but shows a strong increase when 


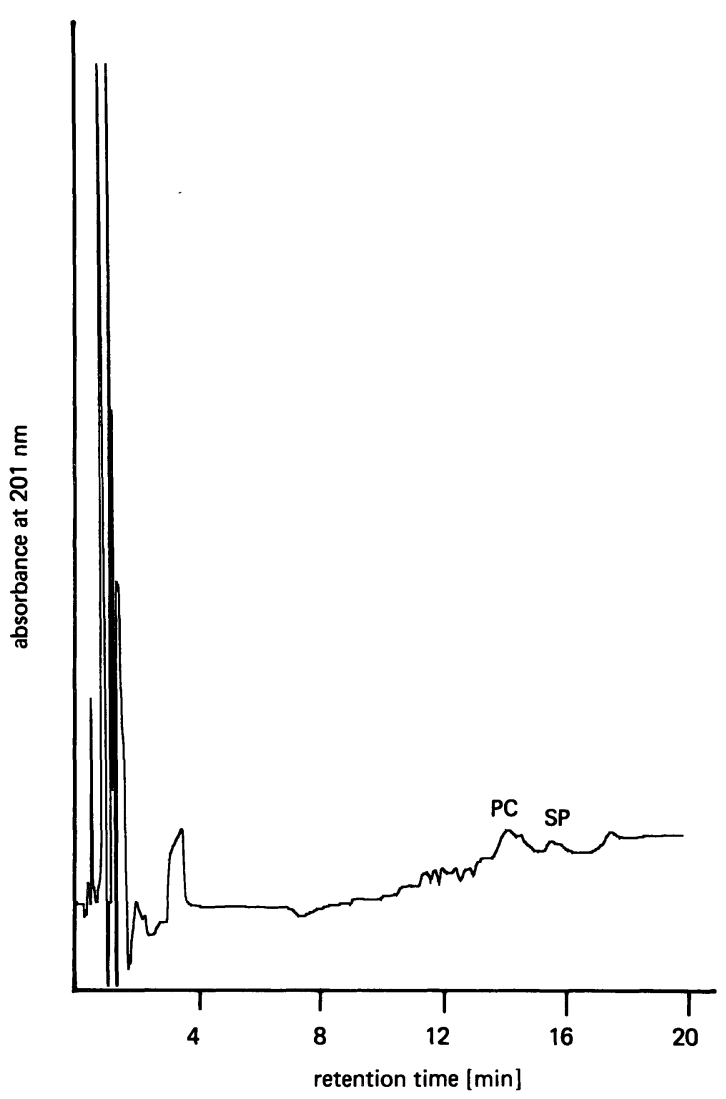

Figure 6. Phospholipids in a meconium sample as determined by HPLC; extraction with chloroform-methanol $(2: 1, \mathrm{v} / \mathrm{v})$ and acetone precipitation of $2.0 \mathrm{ml}$ of a meconium water suspension containing $5.0 \mathrm{mg}$ meconium $/ \mathrm{ml}$. Peaks see figure 1. amniotic fluid is contaminated by blood. The PC and SP concentrations in amniotic fluid are as well slightly influenced by contamination with meconium and extremely dependent on the contamination with blood. From the methods which are commonly used to determine fetal lung maturity, only the analysis of PG can be recommended in cases with contamination by meconium and blood. The analysis of PC can be used to a limited extent when meconium staining is present, whereas in the case of blood contamination, PC should not be used as an indicator of fetal lung maturity.

\section{Summary}

This paper presents the evaluation of the effects of blood and meconium on the determination of the phospholipids phosphatidylglycerol (PG), phosphatidylinositol (PI), phosphatidylethanolamine (PE), phosphatidylcholine (PC), sphingomyelin (SP) and lysolecithin (LL) in amniotic fluid. Phospholipids were analyzed by a new method using high pressure liquid chromatography (HPLC), which is based on the procedure of BRIAND et al. [1]. The method was extended for quantitative determination with lysolecithin as internal standard. The HPLC equipment consisted of two pumps, an HPLC programmer, an HPLC oven, a UV detector and an integrator. The chromatographic separation was achieved on a $25 \mathrm{~cm}$ DIOL-column and a $6 \mathrm{~cm}$ guard column packed with silica SI 60 . The oven temperature was $55^{\circ} \mathrm{C}$ and the detector wave length was $201 \mathrm{~nm}$. The chromatographic mobile phase was composed of two solvents, acetonitrile and water. A solvent gradient was run from $2.4 \%$ water to $15 \%$ water between 5 and 13 minutes. Phospholipids were extracted according to the procedure of GLUCK [8]. Before extraction $40 \mu \mathrm{g}$ of $\mathrm{LL}$ as internal standard were added to $2.0 \mathrm{ml}$ amniotic

fluid. In a standard solution the phospholipids PE, PC, SP and LL were baseline separated, in the case of PG and PI a perpendicular division of the peaks was necessary.

To evaluate the effect of contamination by blood and meconium, various amounts of blood and meconium were added to uncontaminated amniotic fluid samples. Contamination by blood caused a rise of the concentrations of PC, PE and SP up to tenfold. PG and PI concentrations were not affected by blood staining. HPLC analysis proved that blood contains only PE, PC and SP in detectable amounts, but no PG and PI. In specimens with blood contaminants, only PG and PI are reliable indicators of fetal lung maturity. The concentrations of PG, PI and PE were not affected by meconium staining. PC and SP values showed an ascending drift up to a maximum rise of $20 \%$ resp. $10 \%$. HPLC analysis showed that meconium contains small amounts of PC and SP, but no PG, PI and PE. PC and SP determinations are therefore practicable only in slightly meconium stained specimens. 
From the determination methods which are widely accepted for the assessment of fetal lung maturity, only the analysis of PG is not affected by blood and meco- nium. PC analysis cannot be used in cases of blood contaminants and only to a limited extent in meconium contaminants.

Keywords: Amniotic fluid, blood, fetal lung maturity, HPLC, meconium, phospholipids.

\section{Zusammenfassung}

Einfluß von Blut und Mekonium auf die Bestimmung von Phospholipiden im Fruchtwasser mittels Hochdruckflüssigkeitschromatographie

Die vorliegende Arbeit beschreibt den Einfluß von Blut und Mekonium auf die Bestimmung der verschiedenen Phospholipide Phosphatidylglycerol (PG), Phosphatidylinositol (PI), Phosphatidylethanolamin (PE), Phosphatidylcholin (PC), Sphingomyelin (SP) und Lysolecithin (LL) im Fruchtwasser. Die Phospholipide wurden mit einer neuen Bestimmungsmethode mittels Hochdruckflüssigkeitschromatographie (HPLC) bestimmt. Die Methode geht auf BRIAND et al. [1] zurück und wurde von uns unter Verwendung von Lysolecithin als internem Standard zur quantitiativen Bestimmungsmethode erweitert. Die HPLC-Anlage bestand aus 2 Pumpen, einem Gradientengeber, einem HPLC-Ofen, einem UV-Detektor und einem Integrator. Die chromatographischen Trennungen erfolgten mit Hilfe einer 25 $\mathrm{cm}$ DIOL-Hauptsäule und einer $6 \mathrm{~cm}$ Vorsäule mit Silica SI 60. Die Ofentemperatur betrug $55^{\circ} \mathrm{C}$ und die Wellenlänge lag bei $201 \mathrm{~nm}$. Die mobile Phase bestand aus 2 Lösungsmitteln, Acetonitril und Wasser. Zwischen 5 und 13 Minuten wurde ein Lösungsmittelgradient von $2.4 \%$ bis $15 \%$ Wasser verwendet. Die Extraktion der Phospholipide erfolgte nach GLUCK [8]. Vor der Extraktion wurden $40 \mu \mathrm{g}$ Lysolecithin als interner Standard zu $2.0 \mathrm{ml}$ Fruchtwasser gegeben. In einer Standardlösung konnten die Phospholipide PE, PC, SP und LL vollständig getrennt werden. Zur Trennung der PG- und PI-peaks war eine Lotfällung auf eine gemeinsame Basislinie notwendig.

Zur Untersuchung des Einflusses von Blut- und Mekoniumverunreinigungen wurden verschiedene Mengen an Blut und Mekonium zu unkontaminierten Fruchtwasserproben gegeben. Bei Verunreinigung mit Blut stiegen die Konzentrationen von PC, PE und SP bis auf die zehnfachen Werte an. Die Konzentrationen von PG und PI blieben von Blutverunreinigungen unbeeinflußt. Durch HPLC-Analyse einer Blutprobe konnte gezeigt werden, daß nur PE, PC and SP und kein PG und PI in nachweisbaren Mengen im Blut enthalten sind. In blutkontaminierten Proben sind nur PG und PI verläßliche Parameter zur Bestimmung der fetalen Lungenreife. Eine Verunreinigung mit Mekonium ließ die Konzentrationen von PG, PI und PE unbeeinflußt. Die PCund SP-Werte stiegen um bis zu $20 \%$ bzw. $10 \%$ bei maximaler Verunreinigung an. Durch HPLC-Analyse einer Mekoniumprobe konnte gezeigt werden, daß Mekonium nur geringe Mengen an PC und SP enthält, aber kein PG, PI und PE. PC und SP können daher nur in leicht mekoniumverunreinigten Proben bestimmt werden.

Von den allgemein anerkannten Lungenreifebestimmungsmethoden wird nur die Analyse von PG von Blutund Mekoniumverunreinigungen nicht beeinflußt. Die Bestimmung von PC sollte bei bluthaltigen Fruchtwasserproben unterbleiben und bei mekoniumhaltigen nur bei geringer Verunreinigung verwendet werden.

Schlüsselwörter: Blut, Fruchtwasser, HPLC, Lungenreife, Mekonium, Phospholipide.

\section{Résumé}

Influence de la présence de sang et de méconium sur l'étude des phospholipides dans le liquide amniotique par chromatographie en phase liquide à pression élevée Cet article présente l'évaluation des effets du sang et du méconium sur l'étude des phospholipides, phosphatidylglyceŕrol (PG), phosphatidylinositol (PI), phosphatidylethanolamine (PE), phosphatidylcholine (PC), sphingomyeline (SP) et lysolécithine (LL) dans le liquide amniotique. On a analysé les phospholipides par une nouvelle méthode avec chromatographie en phase liquide à pression élevée (H.P.L.C.), fondée sur la technique de Briand et Coll. [1]. La méthode a été élargie pour une détermination quantitative avec la lysolécithine comme standard interne. Le matériel pour H.P.L.C. comprend deux pompes, un programmeur pour H.P.L.C. une étude à H. P. L. C., un détecteur d'U. V. et un intégrateur. La séparation chromatographique est réalisée sur une colonne DIOL de $25 \mathrm{~cm}$ et une colonne de protection de $6 \mathrm{~cm}$ entourée de Silice SI 60 . La température de l'étude est de $55^{\circ} \mathrm{C}$ et la longueur d'onde du détecteur est de $201 \mathrm{~nm}$. La phase mobile de la chromatographie comporte deux solvants, de l'acétonitrile et de l'eau. Le gradient du solvant varie de $2,4 \%$ d'eau à $15 \%$ entre 5 et 13 minutes. On extrait les phospholipides selon la technique de GlucK [8]. Avant, on ajoute $40 \mu \mathrm{g}$ de LL comme standard interne à $2 \mathrm{ml}$ de liquide amniotique. Dans une solution standard, les phospholipides PE, PE, SP et LL sont séparés sur la ligne de base pour PG et PI, il est nécessaire de recourir à une division perpendiculaire des pics.

Afin d'apprécier l'effet de la contamination par le sang et par le méconium, on a ajouté du sang et du méconium en diverses quantités à des échantillons de liquide amniotique non contaminés. La contamination sanguine entraîne une élévation des concentrations de PC, PE et SP jusqu'à dix fois le taux de base. Les concentrations de 
PG et de PI ne sont pas modifiées par la contamination sanguine. L'analyse H.P.L.C. prouve que le sang ne contient que PE, PC et SP en quantité détectables mais pas de PG et de PI. Dans les échantillons contaminés par du sang, seuls PG et PI sont indicateurs valables de la maturité pulmonaire fotale. La contamination méconiale n'affecte pas les concentrations de PG, PI et PE. Les valeurs de PC et SP montrent une courbe ascendante allant jusqu'à un maximum de $20 \%$ respective $10 \%$. L'analyse H.P. L.C. montre que le méconium contient de petites quantités de PC et de SP, mais pas de PG, PI et PE. Toutefois, les dosages de PC et SP ne sont praticables que dans les échantillons légèrement teintés de méconium.

Parmi les méthodes qui sont largement reconnues pour l'estimation de la maturité pulmonaire fœtale, seule l'analyse de PG n'est pas affectée par le sang et le méconium. L'analyse de PC ne peut pas être utilisée lorsqu'il y a une contamination sanguine, et seulement dans certaines limites en cas de contamination méconiale.

Mots-clés: H.P. L.C., liquide amniotique, maturité pulmonaire fœtale, méconium, phospholipides, sang.

Acknowledgements: This work was supported by grants given to the Sonderforschungsbereich 174 by the Deutsche Forschungsgemeinschaft. We would like to thank Mrs. KLAU for skillfull technical assistance and Mrs. FIEGE for her support in translating.

\section{References}

[1] BRIAND RL, S HAROLD, KG Blass: High-performance liquid chromatographic determination of the lecithin/sphingomyelin ratio in amniotic fluid. $\mathrm{J}$ Chromatogr 223 (1981) 277

[2] BUHI WC, WN SPELlaCY: Effects of blood or meconium on the determination of the amniotic fluid lecithin/sphingomyelin ratio. Am J Obstet Gynecol 121 (1975) 321

[3] Bustos R, M Kulovich, L Gluck, C Gabbe, L EVERTSON, C VARGAS, E LOWENBERG: Significance of phosphatidylglycerol in amniotic fluid in complicated pregnancies. Am J Obstet Gynecol 133 (1979) 899

[4] Clements JA, ACG Platzker, DF Tierney, CJ Hobel, KR Creasy, AJ Margolis, DW Thibeault, WH TOOLEY, W OH: Assessment of the respiratory distress syndrome by a rapid test for surfactant in amniotic fluid. N Engl J Med 286 (1972) 1077

[5] Diedrich K, SE Evans, HJ Giebitz, AR Helbing, G KyNAST, T HeINZE, B LIEDTKE, U LORENZ, G Martens, H SChlebusch, V SCHIOLER, P BOUChELOUCHE, O SiggaARd-ANDERSEN, H Sirowey, D WeIHS, ACH Kessler, HO BeUtLeR: Enzymatische Lezithinbestimmung im Fruchtwasser zur antepartalen Lungenreifediagnostik - eine multizentrische Studie. Z Geburtshilfe Perinatol 186 (1982) 19

[6] GARTZKe J, G KynAST, E SALING: Untersuchungen über den Einfluß von Blut- und Mekoniumverunreinigungen auf Methoden zur Bestimmung der Lungenreife des Feten. Ärztl Lab 26 (1980) 231

[7] GluCK L, MV KuLOVICH, RC BORER, PH BRENNER, GG ANDERSON, WN SPellacy: Diagnosis of the respiratory distress syndrome by amniocentesis. Am J Obstet Gynecol 109 (1971) 440

[8] GluCK L, MV Kulovich, RC BoReR, WN KeIDEL: The interpretation and significance of the lecithin/ sphingomyelin ratio in amniotic fluid. Am J Obstet Gynecol 120 (1974) 142
[9] Hallmann M, M Kulovich, E Kirkpatrick, RG Sugarman, L Gluck: Phosphatidylinositol and phosphatidylglycerol in amniotic fluid: Indices of lung maturity. Am J Obstet Gynecol 125 (1976) 613

[10] Keniston RC, GL Noland, ML Pernoll: The effect of blood, meconium and temperature on the rapid surfactant test. Obstet Gynecol 48 (1976) 442

[11] Koszalka MF, CH BlomQuist, DJ LaKatua: Fetal lung maturity assessment by a modified A 650 determination. J Perinat Med 14 (1986) 35

[12] Kynast G, T HeINZE, EZ Saling: A new testcombination for the enzymatic determination of fetal lung maturity. J Perinat Med 9 (1981) 101

[13] KynAST G, EZ SALING: Routine diagnosis of fetal lung maturity. J Perinat Med 2 (1974) 208

[14] Sbarra AJ, RJ Selvaraj, Cl Cetrulo, Jl KenNEDY, MJ HERSCHEL, R KNUPPEL, H KAPPY, GW Mitchell, EC Kelley, BB Paul, FJ Lous: Positive correlation of optical density at $650 \mathrm{~nm}$ with lecithin/sphingomyelin ratios in amniotic fluid. Am J Obstet Gynecol 130 (1978) 788

[15] Strassner HT, S Golde, G Mosley, L Platt: Effect of blood in amniotic fluid on the detection of phosphatidylglycerol. Am J Obstet Gynecol 138 (1980) 697

[16] Yambao TJ, B Tawwater, J Chuachingco, A CaRILLO, D SCHWARTZ: Effects of meconium on the detection of phosphatidylglycerol. Am J Obstet Gynecol 150 (1984) 426

Received February 17, 1987. Revised July 22, 1987. Accepted September 11, 1987.

Dr. rer. nat. Thomas Heinze

Institute of Perinatal Medicine - The Free

University of Berlin and Department of Obstetrics

Women's Hospital, Berlin-Neukölln

Mariendorfer Weg 28

D-1000 Berlin 44, West Germany 